\title{
Cellulolytic yeast from gastrointestinal tract of muscovy duck (Anas moscata) as probiotic candidate
}

\author{
A. S. Anggraeni*, L. Istiqomah, E. Damayanti, M. Anwar, A. A. Sakti and M. F. Karimy \\ Research Unit for Natural Product Technology (BPTBA), Indonesian Institute of Sciences \\ (LIPI), Gading, Playen, Gunungkidul, D.I. Yogyakarta - Indonesia \\ *Corressponding E-mail: ayu.anggraeni07@gmail.com
}

Received March 22, 2018, 2018; Accepted August 09, 2018

\begin{abstract}
ABSTRAK
Selulosa merupakan salah satu faktor pembatas pada pakan unggas lokal. Eksplorasi khamir dari saluran cerna unggas lokal dan pemanfaatannya sebagai kandidat probiotik belum banyak dikaji. Sebanyak 112 isolat khamir diperoleh dari saluran cerna Mentok, Bebek dan Ayam Kampung pada bagian usus halus, sekum dan kolon. Khamir dengan aktivitas selulolitik diseleksi secara kuantitatif menggunakan media CYG Agar $+1 \%$ CMC dengan waktu inkubasi $30{ }^{\circ} \mathrm{C}$ selama 48 jam pada kondisi anaerob. Sebanyak 107 isolat khamir memiliki aktivitas selulolitik. Isolat khamir M41 dari bagian sekum Mentok memiliki zona jernih aktivitas selulolitik tertinggi sebesar 0,64 cm. Karakterisasi khamir M41 meliputi identifikasi molekuler, pengujian kemampuan pertumbuhan dalam medium kombinasi CMC dan glukosa, aktivitas CMCase, dan uji viabilitas kemampuan probiotik dengan variasi waktu. Hasil penelitian diketahui bahwa khamir M41 memiliki kedekatan 98\% dengan Saccharomyces cerevisiae berdasarkan analisis sekuen gen 26S sRNA, optimum tumbuh pada medium mengandung CMC $1 \%$ dan $0,1 \%$ glukosa (b/v), aktivitas CMCase sebesar $42,98 \mathrm{U} / \mathrm{mL}$, dan memiliki viabilitas sebesar 91,91; 66,22; 42,00; 42,00; 1,83 dan 42,13 (\%) berturut - turut pada garam empedu 2 jam dan 3 jam, getah lambung 45 menit dan 2 jam, $\mathrm{pH} 2$ dan $\mathrm{pH} 3$ selama 90 menit. Berdasarkan hasil penelitian, disimpulkan bahwa $S$. cerevisiae M41 berpotensi sebagai kandidat probiotik untuk unggas dengan aktivitas selulolitik.
\end{abstract}

Kata kunci: aktivitas selulolitik, khamir, Mentok, probiotik

\begin{abstract}
Cellulose is one of limiting factors in local poultry feed. Yeast exploration of local poultry gastrointestinal tract and its utilization as a probiotic candidate has not been widely studying. A total of 112 isolates of yeast were obtained from the digestive tract of Muscovy Duck, Javanesse Duck and Indonesian Native Chicken in the small intestine, cecum, and colon. Yeast with cellulolytic activity was quantitatively selected using CYG agar $+1 \%$ CMC medium with an incubation time of $30^{\circ} \mathrm{C}$ for 48 hours under anaerobic conditions. A total of 107 isolates of yeasts have cellulolytic activity. M41 yeast isolates of Mentok cecum possess highest clear zones cellulolytic activity $(0.64 \mathrm{~cm})$. M41 yeast characterization includes molecular identification, growth ability testing in CMC and glucose combination medium, CMCase activity, and viability test of probiotic ability with time variation. The results showed that yeast M41 had 98\% proximity with Saccharomyces cerevisiae based on 26S sRNA gene sequence analysis, optimum growth on medium containing $1 \% \mathrm{CMC}$ and $0.1 \%$ glucose $(\mathrm{b} / \mathrm{v})$, CMCase activity of $42.98 \mathrm{U} / \mathrm{mL}$, and has a viability of $91.91 ; 66.22 ; 42.00 ; 42.00 ; 1.83$ and $42.13(\%)$ respectively on bile salts 2 hours and 3 hours, gastric juice 45 minutes and 2 hours, $\mathrm{pH} 2$ and $\mathrm{pH} 3$ for 90 minutes. Based on results of the study, it was concluded that S. cerevisiae M41 potentially as a probiotic
\end{abstract}


candidate for poultry with cellulolytic activity.

Keywords: cellulolytic activity, yeast, Muscovy duck, probiotic

\section{INTRODUCTION}

The growth rate of egg-type poultry can be improved through the increase in feed quality that provides impacts on better productivity either quantity or quality. High fiber in the dietary poultry feed will reduce feed digestibility and the animal productivity. The plant cell wall is consisting of lignin and non-starch polysaccharides (NSP) (Walugembe, 2013). Polysaccharides classification based on differences in solubility are cellulose, hemicellulose, pectin, and lignin (Albersheim et al., 1984). Cellulose is a linear chain-shaped glucose polymer and is connected by a $\beta-1,4$ glycosidic bond. Cellulose is made up of 8,000 12,000 glucose units connected by $\beta-1,4-$ glycoside bonds (Fikrinda et al., 2000). The $\beta$ 1,4-glycoside bond on cellulose fibers can be broken down into glucose monomers by cellulase. Cellulase is one of the enzyme groups included in a system produced by microorganisms in the degradation of plant cell material. Cellulase consisting of three major enzyme types: endo-1,4$\beta$-glucanase, ekso-1,4- $\beta$-glucanase or cellobiohydrolase, and $\beta$-D-glucosidase that works together to hydrolyze cellulose into glucose (Fikrinda et al., 2000; Belitz et al., 2008; Gao et al., 2008; Imran et al., 2016).

Applications of cellulases in feed industry have received considerable attention because of their potential to improve nutritional quality of animal feed, digestion and absorption of feed materials, improving performance and health of animals, enhancing fiber degradation in vitro; in situ and in vivo also eliminate antinutritional factors and pathogens in the feed (Bhat, 2000; Asmare, 2014). Cellulase enzymes are usually produced by microbes such as fungi, bacteria and protozoa. It is also produced by plants and animals (Morana et al., 2011). Only a few microorganisms can produce cellulase namely Pseudomonas, Cellulomonas, Bacillus, Cellovibrio, and Sporosphytophaga (Ikram-ul Haq et al., 2005). Composition of yeast microflora, have received little attention (Laubscher et al., 2000). The attention has been given to the intestinal yeast flora of several mammal and bird species, but little to poultry (Van Uden and Castelo-Branrco, 1963). Study from Brilhante et al. (2010) found that the most frequently isolated species from Cockatiels oral cavity, crop and cloaca were Candida albicans (32.5\%), Candida tropicalis (20\%), Trichosporon asteroides (12.5\%), Candida famata (10\%) and others.

Numerous yeast products and yeastcontaining feed ingredients are commercially produced, marketed, and used extensively in animal feeds around the world. Nutritional yeasts are used as supplements in animal feeds due to their relatively high protein and amino acid, energy, and micronutrient content compared with common feed grains and oilseed meals (Shurson, 2018). Yeast also one of important microorganism which was common used as a poultry probiotic to improve production parameter such as absorption of feed (Markowiak and Slizewska, 2018). Yeasts other than $S$. cerevisiae having probiotic properties belong to the genus Pichia, Metschnikowia, Yarrowia, Candida, Debaryomyces, Isaatchenkia, Kluyveromyces. They have importance in improving animal's nutrition and health. Its supplementation to animal feed has been known to enhance the nutritive quality of feed and feed utilization, thus improving the performance of the animal (Syal and Vohra 2013 ).

Meanwhile the information about the yeast with CMCase activity for poultry probiotic agent is still limited. Purposes of the present study was to identify novel potential probiotic yeasts isolated from local poultry especially Muscovy duck's Javanese Duck's and native chicken, gastrointestinal tract (GIT) by testing-their probiotic potential with cellulolytic activity using Carboxymethyl cellulase (CMCase) activity on in vitro assay. Probiotic yeast with cellulolytic activity is expected to improve the digestibility of animal feed with limited nutrition especially for local poultry.

\section{MATERIAL AND METHODS}

\section{Yeast Isolation and Characterization}

Yeast was isolated from Muscovy duck (Anas moschata), Indonesian native chicken (Gallus javanicus) and Javanese Ducks' (Anas javanicus), gastrointestinal tract on small intestine, colon and cecum regions according to Torshizi et al. (2008) method. Lumen from the 
small intestine, cecum and colon was diluted in $\mathrm{NaCl}$ solution $0.85 \%$ (Merck) and made up to $10^{5}$ serial dilutions. One hundred $\mu \mathrm{l}$ of each serial dilution was spread plated (duplo) on CYG Agar media (Oxoid) (Chlorampenicol Yeast Glucose Agar) medium and incubated at $30{ }^{\circ} \mathrm{C}$ for 24 hours in aerobic condition. Yeast isolates were grown in CYG broth contained $15 \%$ glycerol $(\mathrm{v} / \mathrm{v})$ and kept in frozen condition $\left(-80^{\circ} \mathrm{C}\right)$. Yeast isolate was streaked on CYG agar plate to guarantee purity for any assay. Yeast suspected colonies were selected based on the appearance of white and non-shiny colonies and positive catalase test. Observation of yeast morphology was conducted based on Krieg et al. (2010) method.

\section{Screening of Cellulolytic Yeast}

The screening of cellulolytic yeast was performed using clearing zone formation method (Kanti et al., 2002). Preliminary screening of yeast isolates with cellulolytic activity was conducted by inoculated $10 \mu \mathrm{L}$ yeast on paper disk in CYG Agar plate containing 1\% CMC and incubated at $30{ }^{\circ} \mathrm{C}$ for 48 hours in anaerobic condition. Compotition of CMC medium: $1 \mathrm{gr}$ $\mathrm{CMC}, 0.02$ gr $\mathrm{MgSO}_{4} .7 \mathrm{H}_{2} \mathrm{O}, 0.075$ gr $\mathrm{KNO}_{3}$, 0.05 gr $\mathrm{K}_{2} \mathrm{HPO}_{4}, 0.002 \mathrm{FeSO}_{4} .7 \mathrm{H}_{2} 0,0.04$ gr $\mathrm{CaCl}_{2} \cdot 2 \mathrm{H}_{2} \mathrm{O}, 0.2$ gr yeast extract, $1.5 \mathrm{gr}$ bacteriological agar, 0.1 gr glucose in $100 \mathrm{~mL}$ aquades. After incubation, the plates were flooded with Congo red $(1 \%, \mathrm{v} / \mathrm{w})$ for $20 \mathrm{~min}$ then followed by destaining with $1 \mathrm{M} \mathrm{NaCl}$ for $20 \mathrm{~min}$. The yeast strain with the largest clear zone shown the highest cellulolytic activity. Cellulolytic activity measurement with determination of cellulolytic index, which is the ratio between the diameters of a clear zone with a diameter of colonies (Sazci et al., 1986; Kasana et al., 2008; Meryandini et al., 2011).

\section{Molecular Identification of Selected Yeast}

Observation of yeast morphology was conducted based on Krieg et al. (2010) method. Molecular identification of yeast was performed based on genetical partial analysis on region D1/D2 Large Sub Unit (LSU) ribosomal DNA. DNA was extracted by the boiling method at 98 ${ }^{\circ} \mathrm{C}$. The extracted DNA was amplified using a PCR machine. 600 bp region D1 / D2 LSU rDNA amplification process using Go Taq Green Master mix and NL1: 5'-CATATCAATAAGCGGAG GAAAG-3` primer and primer NL4: 5`-
GTCCGTGTTTCAAGACGG-3 on annealing temperature $55{ }^{\circ} \mathrm{C}$ optimization for 30 cycles. Purification of PCR product was performed by PEG precipitation method (Arbeli and Fuentes, 2007) followed by sequencing cycle. The results of the sequencing cycle were regrouped with ethanol purification method. The analysis of nitrogen base sequence reading was using automated DNA sequencer (ABI PRISM 3130 Genetic Analyzer) (Applied Biosystems).

The next sequenced trimming and assembling data using the ChromasPro 1.7.5 program The sequencing results of this study were compared using the Basic Local Alignment Search Tool (BLAST) program on NCBI (http://www.ncbi.nlm.nih.gov/BLAST/) (Altschul et al., 1990). BLAST results that have a molecular level of homologous status determine the name of the taxon/sample species (Kurtzman and Robnett, 1998). A phylogenetic tree was constructed using the Maximum-likelihood model of the MEGA 7 program (Tamura and Nei 1993, Apriliyanto dan Sembiring, 2016, Kumar et al., 2016). Stability of grouping was measured using 2000 bootstrap replicates. The phylogenetic tree was performed by MEGA 7 program.

\section{Cell Growth Analysis}

Cell growth analysis of yeast was performed to determine the yeast ability to consume cellulose with Optical density (OD) as a growth parameter. One percent of $10^{8} \mathrm{CFU} / \mathrm{mL}$ yeast was inoculated into sterile two type of combination medium i.e. only $1 \%$ CMC (medium A) and $1 \%$ $\mathrm{CMC}+0.1 \%$ glucose. The culture were incubated for $72 \mathrm{~h}$ at $30^{\circ} \mathrm{C}$, aerobic condition. Cell growth was measured at $0,24,48$, and 72 hours using a microplate reader at a wavelength of $640 \mathrm{~nm}$. After incubation, culture isolates were vortexed and $225 \mathrm{~mL}$ was put into microplate (Chorianopoulos et al., 2006; Sutton 2011; Szermer-Olearnik 2014).

\section{Carboxymethyl Cellulase (CMCase) Activity Assay}

Yeast with cell density $10^{8} \mathrm{CFU} / \mathrm{mL}$ was evaluated for Carboxymethyl cellulase activity (CMCase) by determination of reducing sugar using dinitrosalicylic acid reagent (DNS) according to Ghose method (Ghose, 1987). A reaction media containing $0.5 \mathrm{~mL}$ CMC substrate dissolved in citrate buffer (acidity 4.8 ) and $0.5 \mathrm{~mL}$ enzymatic crude extract and incubated at $50{ }^{\circ} \mathrm{C}$ 
for $30 \mathrm{~min}$. The reaction was terminated by the addition of $1.5 \mathrm{~mL}$ of DNS reagent and boiled in the water bath at $100{ }^{\circ} \mathrm{C}$ for $5 \mathrm{~min}$, cooled at room temperature and then added $10 \mathrm{~mL}$ of distilled water. The amount of reducing sugars released was determined by measurement at a wavelength of $540 \mathrm{~nm}$ (Ghose, 1987).

Critical enzyme concentration (IU) $=0.185 \mathrm{x}$ CMC (sugar reduction) (mg) (Ghose, 1987).

\section{Probiotic Assay of the Selected Strain}

Probiotic assay was determined by modified method of Torshizi et al. (2008) consisted of bile salt assay, acid assay and gastric juice tolerant assay with viability percentage as parameters. In bile salt assay, $1 \mathrm{~mL}$ yeast culture was centrifuged at $4137 \times \mathrm{g}$ for $10 \mathrm{~min}$ at $4{ }^{\circ} \mathrm{C}$ and washed twice by using sterile PBS. The cells were diluted in 0.3 $\mathrm{mL}$ of PBS then mixed with $0.2 \mathrm{~mL}$ of dilution and $1 \mathrm{~mL}$ PBS containing $0.3 \%(\mathrm{w} / \mathrm{v})$ bile salt (Merck). The mixture was incubated at $30{ }^{\circ} \mathrm{C}$ for $3 \mathrm{~h}$ and then was sampled after 2 and $3 \mathrm{~h}$. The cell viability was calculated by using serial dilution and plated on CYG Agar media. Three replications were used for each treatment. In acid tolerance test yeast cultures on CYG Broth medium were centrifuged at $4137 \mathrm{x}$ g for $10 \mathrm{~min}$ at $4{ }^{\circ} \mathrm{C}$. Pellets were washed two times by sterile phosphate buffered saline (PBS) and diluted in sterile PBS before being inoculated on $\mathrm{CYG}$ Broth (pH 2, and $\mathrm{pH} 3$ with $1 \mathrm{M} \mathrm{HCl}$ addition). Cell viability was calculated by the total plate count (TPC) method on CYG Agar media after 90 min incubation in acid. In gastric juice tolerance assay, yeast isolates were incubated on $\mathrm{CGY}$ Broth at $30{ }^{\circ} \mathrm{C}$ for $18 \mathrm{~h}$. A total of $1 \mathrm{~mL}$ culture was centrifuged at $5000 \mathrm{~g}, 10 \mathrm{~min}, 4{ }^{\circ} \mathrm{C}$ then it was washed two times by using sterile PBS and diluted on $0.3 \mathrm{~mL}$ sterile PBS. A total of $0.2 \mathrm{~mL}$ dilution was taken and then mixed with $1 \mathrm{~mL}$ of artificial gastric juice. The mixture liquid was homogenized and incubated at $37^{\circ} \mathrm{C}$ for $2 \mathrm{~h}$ and then sampled after $45 \mathrm{~min}$ and $2 \mathrm{~h}$. Serial dilutions of samples was made on sterile PBS and then inoculated on CYG Agar media for cell viability observation. The artificial gastric juice was made from pepsin (Sigma) $(3 \mathrm{~g} / \mathrm{l}$ ) dilution at $\mathrm{pH} 2$.

\section{Data Analysis}

The data of clear zone diameter, CMCase activity and viability percentage of probiotic assay were evaluated using the analysis of variance (ANOVA) and the differences among mean treatments were analyzed using Duncan's Multiple Range Test (Gomez and Gomez, 2007). Statistical analyses were performed with Costat (Cohort, 2008).

\section{RESULT AND DISCUSSION}

\section{Yeast Isolation and Characterization}

Isolation result showed that there were 112 of isolates predicted as yeast based on morphological appearance (31 isolates from native chicken, 20 isolates from Javanese duck, and 61 isolates from Muscovy duck) (Table 1). According to Table 1, the gastrointestinal tract of Muscovy duck's has the largest number of yeast colonies and the cecum region of Muscovy duck's

Table 1. Total Yeast Isolate from Gastrointestinal of Javanese duck, Muscovy duck and Native Chicken

\begin{tabular}{llc}
\hline \multicolumn{1}{c}{ Source of Host } & Gastrointestinal Tract & Number of Yeast Isolate \\
\hline Javanese Duck's & Small intestine & 10 \\
& Cecum & 6 \\
\multirow{3}{*}{ Muscovy Duck's } & Colon & 4 \\
& Small intestine & 16 \\
& Cecum & 25 \\
\multirow{2}{*}{ Native Chickens } & Colon & 20 \\
& Small intestine & 7 \\
& Cecum & 7 \\
\hline Total isolate & Colon & 17 \\
\hline
\end{tabular}


has the highest number of yeast. Roto et al. (2015) stated that every area of the gastrointestinal tract has different microbial communities. Al-Shimmery (2011) reported that 58 yeast isolated from intestinal tracts of 35 out of 50 birds belonging to Saccharomyces (31.03\%), Candida glabrata $(20.69 \%), \quad$ C. tropicalis (15.51\%), C. albicans (15.51\%), C. fmata and Creptococcus neoformans (8.62\%).

Yeasts are single cell, eukaryotic microorganisms, microscopic fungi are generally about 3-4 $\mu \mathrm{m}$ in size, have a nuclear membrane and cell walls, and characterized as heterotrophs. Reproduction occurs by budding and fission. Yeasts are considered facultative anaerobes, they can survive and grow in the presence or absence of oxygen. Yeast propagation occurs under aerobicbconditions, and cells convert oxygen and sugars into carbon dioxide and energy through oxidative metabolism to allow efficient yeast cell growth (Shurson, 2018).

\section{Screening of Cellulolytic Yeast}

Screening methods of cellulolytic yeast on $\mathrm{CMC}$ medium and Congo red staining showed that from 112 yeast isolates, 107 yeast isolates had cellulolytic activity characterized by clear zone appearance around the colony as shown on Figure 1. This result was accordance with Pavlostathis et al. (1988) and Valjamae (2002) who reported that cellulose degradation activity can be seen based on the ratio of diameter of clear zone and colony a diameter, so there is are a relationship between clear zone with cellulolytic activity. From 107 yeast isolates which had cellulolytic activity then selected 6 isolates with the largest clearing zones diameter $(\mathrm{P}<0.05)$ (Table 2$)$. The largest clearing

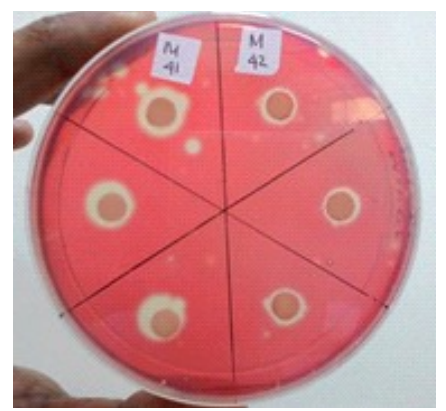

Figure 1. The cellulolytic activity assay of yeast isolate on CYG Agar + 1\% CMC with Congo red $(1 \%, v / w)$ staining, with $30{ }^{\circ} \mathrm{C}$ for 48 hours, anaerobic condition. zone diameter was obtained from M41 isolate which was isolated from cecum of Muscovy duck $(0,64 \mathrm{~cm})$. This result was higher than yeast species which were isolated form Raja Ampat soil such as Barnettozyma california $(0.3 \mathrm{~cm})$, Cryptococcus bestiolae $(0.4 \mathrm{~cm})$, Candida sonorensis $(0.6 \mathrm{~cm})$ but lower than Rhodosporidium paludigenum $(1.3 \mathrm{~cm})$ and Cryptococcus falvescens $(0.83 \mathrm{~cm})$ (Kanti et al., 2012). This yeast isolates were produced higher clear zone diameter compared to cellulolytic bacteria from the gut of Worker Macrotermes gilvus, i.e. 0.05 to $0,145 \mathrm{~cm}$ (Ferbiyanto, et al., 2015) and relatively higher than cellulolytic bacteria such as Burkholderia, Bacillus, Chryseobacterium, Citrobacter and Dyella which has isolated from different natural reserves of the subtropical region in China (Liang et al., 2014).

Plate-screening methods using dyes are not quantitative or adequately sensitive, and because of the poor correlation between enzyme activity and the size of the clear zone, a selective media cannot accurately reflect the cellulolytic activity of bacteria (Maki et al., 2009). Yeast isolates with CMCase activity could hydrolyze cellulose into glucose and showed remarkable clear zone around the colony.

Clear zone formation was caused by the ability of microbe to produce enzimes, therefore to ensure that the clear zone formed due to cellulolytic activity, isolates were stained using congo red and destained with $\mathrm{NaCl}$. The hydrolyzed cellulose of the media (CYGAgar),

Table 2. Clear Zone Diameter of the Selected Yeast Isolated from Muscovy duck, Javanese Duck and Native Chicken

\begin{tabular}{ccc}
\hline $\begin{array}{c}\text { Isolate } \\
\text { Code }\end{array}$ & Host & $\begin{array}{c}\text { Clear Zone } \\
(\mathrm{cm})\end{array}$ \\
\hline M41 & Muscovy duck & $0.64^{\mathrm{c}}$ \\
B17 & Javanese duck & $0.59^{\mathrm{bc}}$ \\
M48 & Muscovy duck & $0.56^{\mathrm{ab}}$ \\
B18 & Javanese duck & $0.51^{\mathrm{ab}}$ \\
A37 & Native chicken & $0.50^{\mathrm{a}}$ \\
A27 & Native chicken & $0.49^{\mathrm{a}}$ \\
\hline
\end{tabular}

Average in the same column with different superscript shown significantly different $(\mathrm{P}<0.05)$. 
when flooded by Congo red would produce a clear zone due to a reaction between Congo red and $\beta$-1,4-glycosidic bonds contained in the cellulose polymer. Congo red has been used as an indicator for beta-D-glucan degradation in an agar media and provides the basis for a rapid and sensitive screening test for cellulolytic bacteria (Teather and Wood, 1982). Bacteria which produce clear zone on CMC agar were selected to test further the CMCase activity using DNS method because it's indicated that microbes might have CMCase activity. Cellulose was hydrolyzed due to the activity of cellulolytic enzymes produced by microbes. According to Goldbeck et al. (2012), out of a total of 390 wild yeast strains isolated, only 5 isolates with the highest cellulolytic activity were characterized by clear zones around colonies in both substrates (carboxymethyl cellulose and cellulose). Thongekkaew and Kongsanthia (2016) reported there were 45 yeast strains had cellulose hydrolytic activity based on clear zones formed on carboxymethyl cellulose containing media as a single carbon source.

\section{Molecular Identification of Selected Yeast}

Characterization of yeast was based on partial genetic analysis in the ribosomal DNA D1/D2 Large Sub Units (LSU) region to determine the genus and strain. Species from the National Center for Biotechnology Information GenBank database showing a high degree of sequence similarity with the colonies that were sequenced and classified based the source of isolation. BLAST homology of $26 \mathrm{~S}$ rRNA sequences in NCBI site revealed that M-41 isolate was identified as Saccharomyces cerevisiae with a length of 519 bp in DNA bank database (NCBI) had $98 \%$ of max identity, 817 of the max score, 817 of the total score, $92 \%$ of query coverage, and 0.0 of E-value. Phylogenetic analysis of M-41 isolate by nucleotide reference from Gen Bank data in NCBI was shown in Figure 2. Branch lengths are proportional to genetic distances. Bootstrap values of over $66 \%$ are shown for 2,000 replicate datasets (Felsenstein, 1985). The tree describes the relationship between selected sequences retrieved from the GenBank database and nucleotide sequences in this study. The phylogenetic tree showed that $S$. cerevisiae M-41 isolated from Muscovy duck was closely related to $S$. cerevisiae isolate jiuqu 3hao $26 \mathrm{~S}$ Ribosomal RNA gene (accession number KX119941.1) based on the D1/D2 regions (Figure.2). The yeast was classified in the Kingdom of Fungi, Phylum of Ascomycota, Subphylum of Saccharomycotina, Order of Saccharomycetales, Family of Saccharomycetaceae, Genus of Saccharomyces, and Species of $S$. cerevisiae. Al-Shimmery (2011) reported that 58 yeasts isolated from intestinal tracts are dominated by Saccharomyces (31.03\%). Goldbeck et al. (2012) reported that AAJ6 isolates with the highest hydrolytic activity in carboxymethyl cellulose $(0.33 \mathrm{U} / \mathrm{mL})$ were identified molecularly by sequencing ITS1-5.8SITS2 and D1 / D2 domains from the ribosome subunit DNA $(26 \mathrm{~S})$ as yeast-like fungi Acremonium strictum. Several studies reported that $S$. cerevisiae isolated from chicken feces (Rajkowska and Kunicka-Styczyska, 2010) and also found in human and animal gastrointestinal tracts and commonly found in food and fermented products. A study by Syal and Vohra (2013), showed that twenty yeast strains were isolated from traditional Indian fermented foods (idli and jalebi batter) and all of these isolates identified as $S$. cerevisiae. In several study $S$. cerevisiae commonly added as a feed additive in animal feed. $S$. cerevisiae can be a very useful tool to reduce lactate accumulation in vitro during fermentation of soluble sugars (Chaucheyras et al, 1996). Dietary yeast supplementation in feed improved growth performance of broiler chickens (Zhang et al., 2005).

\section{The Cell Growth Analysis of $S$. cerevisiae M41 on CMC Media}

The cell growth of Saccharomyces cerevisiae M41 on different composition of CMC was showed in Figure 3. S. cerevisiae M41 has the higher cell growth in $1 \% \mathrm{CMC}+0.1 \%$ glucose medium than only in $1 \% \mathrm{CMC}$ as sole carbon source. Optical density (OD) is an early stage in determining enzyme activity to determine the approximate number of cells present in each bacterial inoculum (Chorianopoulos et al., 2006; Sutton 2011; Szermer-Olearnik 2014). Kanti (2003) reported $0.1 \%$ glucose addition into medium could increase the growth of yeast cell biomass. According to Gohel et al. (2014) CMC is the best substrate to induce the synthesis of extracellular cellulolytic enzymes, $1 \%$ cellulose concentration is the optimum concentration for cellulase production at 24 hours optimum time. Yang (2014) also stated that yeast able to produce cellulase enzyme after 48 hours of fermentation. The exponential phase where the cell begins to divide until reaching the maximum population on 


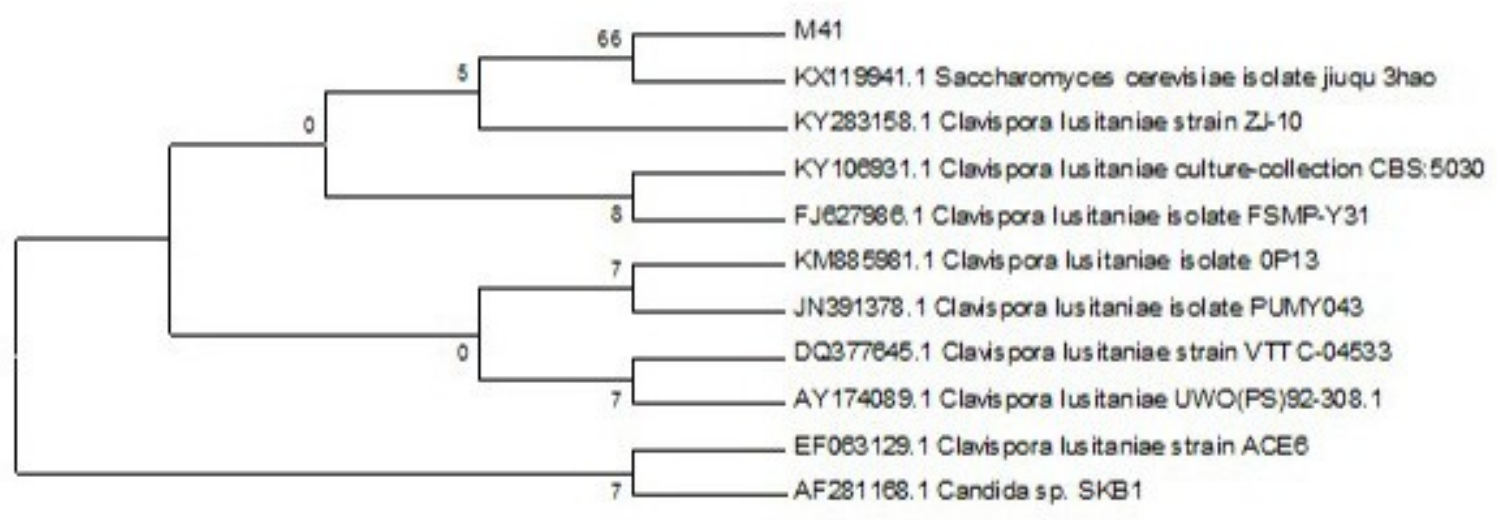

Figure 2. Phylogenetic tree of M-41 isolate Muscovy Duck Cecum Based on Sequence Analysis of 26S Ribosomal RNA Rene on the D1/D2 Regions

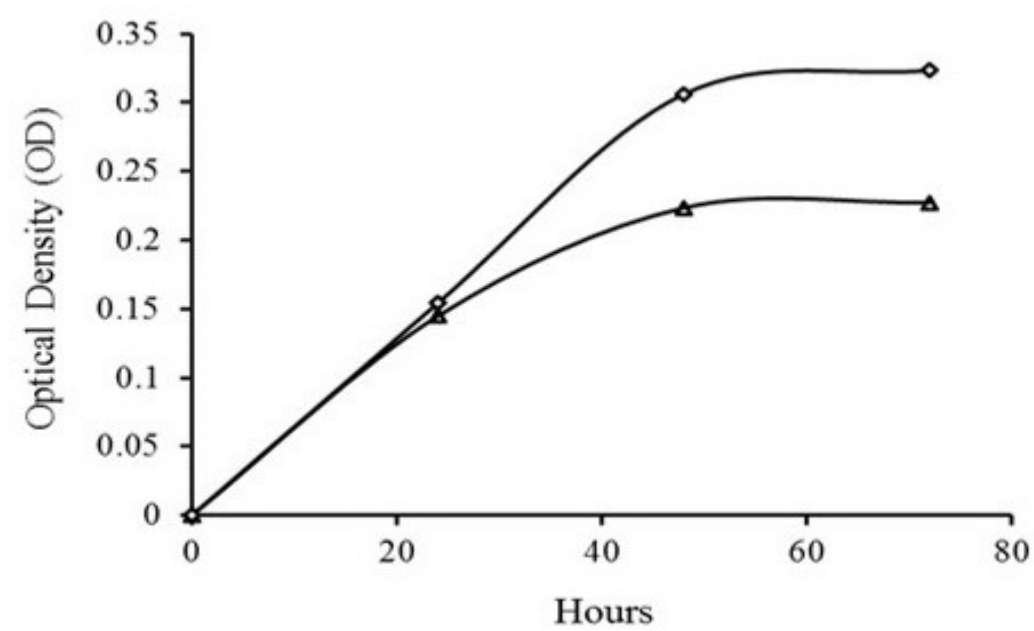

Figure 3. Cell growth analysis of Saccharomyces cerevisiae M41 in 1\% CMC (A) and 1\% CMC $+0.1 \%$ (B) glucose as carbon source, $30{ }^{\circ} \mathrm{C}$ for 72 hours with anaerobic condition. The symbols represent Medium A $(\Delta)$ and Medium B $(\diamond)$

media. Meryandini (2011) mentioned that exponential phase at 48 hours is the optimal phase of bacterial and yeast. Based on OD value (Figure 2 ), the log phase or a growth phase occur until the 48 hours and reached stationary phase at the 48 to 72 hours. S. cerevisiae M41 was still capable to hydrolyzed $\mathrm{CMC}$ into glucose and used for growth until 72 hours.

Based on data of cell optical density (OD) and clear zone diameter, it can be concluded that yeast M-41 was able to hydrolyze cellulose components on CMC medium. The higher absorption of cell density indicated that there was a higher number of bacteria to degrade CMC. It is appropriate in the study that the number of growing cells was assumed to be directly proportional to the number of enzymes produced (Palmer and Bonner, 2011).

\section{CMCase Activity of $\boldsymbol{S}$. cerevisiae M41}

Carboxymethylcellulose (CMCase) activity of $S$. cerevisiae M41 on $1 \%$ CMC medium and $1 \% \mathrm{CMC}+0.1 \%$ glucose was showed in Table 3 . The reducing sugar level and CMCase activity of $S$. cerevisiae M41 in $1 \% \mathrm{CMC}+0.1 \%$ glucose (232 ppm; 42,98 U/mL) was higher than $1 \%$ 
Table 3. Level of Reducing Sugar and Enzyme Activity (CMCase) of Saccharomyces cerevisiae M41 Isolated from Muscovy Duck Cecum

\begin{tabular}{lcc}
\hline Medium & Reducing Sugar (ppm) & CMCase Activity $(\mathrm{U} / \mathrm{mL})$ \\
\hline $1 \% \mathrm{CMC}$ & 203 & 37.56 \\
$1 \% \mathrm{CMC}+0.1 \%$ glucose & $232^{* *}$ & $42.98^{* *}$ \\
\hline
\end{tabular}

Average in the same column with symbol ** shown significantly different $(\mathrm{P}<0.01)$.

CMC medium as a sole carbon (203 ppm; 37.56 $\mathrm{U} / \mathrm{mL}$ ). This result was similar with cell growth analysis. Kanti et al. (2002) also reported that Debaryomyces $s p$. as a cellulolytic yeast have the higher CMCase activity in medium with glucose addition than without glucose.

The CMCase activity of $S$. cerevisiae M41 in this study was higher than in several other studies. Goldbeck et al. (2012) stated that AAJ6 isolate has cellulolytic activity on CMC only 0.33 $\mathrm{U} / \mathrm{mL}$. Thongekkaew and Kongsanthia (2016) also reported that 3 selected yeast of 45 yeast strains showed the low cellulose hydrolytic activity (cellulolytic) $(0.224,0.238$ and 0.26 $\mathrm{U} / \mathrm{mL}$ ). Kanti et al. (2002) revealed that Debaryomyces $s p$. as a cellulolytic yeast isolated from soil Gunung Halimun National Park have the highest CMCase activity in medium with glucose addition only $12 \mathrm{U} / \mathrm{mL}$ at 96 incubation times. Kanti et al. (2012) also reported that Rhodosporidium paludigenum RA29 isolated from Raja Ampat soil have low CMCase activity $0.5 \mathrm{U} / \mathrm{mL}$. The $S$. cerevisiae strain in other studies has the higher CMCase activity than $S$. cerevisiae M41. Hong et al. (2014) reported that $S$. cerevisiae $\mathrm{W} 3$ strain have the highest CMCase activity $(65 \mathrm{U} / \mathrm{mL})$ between 3 other strains with enhanced cellobiohydrolase activity.

According to Muthuvelayudham (2006) CMCase enzyme activity was driven by glucose limitation in the medium at the beginning of cultivation. Rapid cell growth leads to increased nutritional requirements, this condition became positive stimulants of cells to secrete CMCase enzymes that hydrolyse CMC. The presence of CMC in the media is an inductor of CMCase enzyme activity (Kanti, 2003). Cellulase enzyme is a collection of several enzymes that work together for cellulosic hydrolysis (Belitz et al., 2008). Cellulase capability is highly dependent on the substrate used.

Acid, Gastic Juice and Bile Salt Tolerance Assay
The result of low $\mathrm{pH}$ tolerant assay (pH 2 and 3), M41 isolates on 90 minutes incubation had medium viability percentages in $\mathrm{pH} 3(42.13 \%)$ and lower viability percentage in $\mathrm{pH} 2(1.83 \%)$ that were shown on Figure 4. M 41 isolate was found to tolerate these low $\mathrm{pH}$ conditions. At $\mathrm{pH} 2$ the reduction in viability was more as compared to reduction in $\mathrm{pH} 3$. This result has the same with reported by Sourabh et al. (2012) S. cerevisiae (HM535662) was found to tolerate at $\mathrm{pH} 2$ of simulated gastric juice, the reduction in viability was more (2.71 to $4.12 \log \mathrm{CFU} / \mathrm{mL}$ ) as compared to reduction in $\mathrm{pH} 3$ (0.88 to $3.06 \log \mathrm{CFU} / \mathrm{mL}$ ). Survival in low $\mathrm{pH}$ may be due to various factors like cell size, composition of cell wall $\mathrm{pH}$ and strain variations etc (Czerucka et al., 2007; Sofyan et al., 2013; Damayanti et al., 2014).

On gastric juice $(\mathrm{pH} 2)$ tolerant assay, M41 isolates showed cell viability percentage $42 \%$ during $45^{\prime}-2 \mathrm{~h}$ incubation. $M 41$ isolate had equal viability. This result indicate that M41 isolate has tolerance on gastric juice. Tolerance to gastrointestinal juices is an important trait of good probiotic because probiotics entering the GI tract must be resistant to local stresses such as the presence of GI enzymes and $\mathrm{pH}$ (Sourabh et al., 2012).

Based on Figure 4, it was concluded that M41 isolates had decrease viability on $0.3 \%$ of bile salt for 2 and 3 hours incubation (91.91\%$66.22 \%$ ), this result similar with result study of Damayanti et al (2012) that LAB had higher cell viability on $0.3 \%(\mathrm{~b} / \mathrm{v})$ bile salt at one hour of incubation than three hours of incubation. In this case, bile salt tolerances were though to be an important aspect of survival for yeast which inhabit the intestinal tract. Bile salt tolerance in intestinal lactobacilli assosiated with bile salt hydrolase (BSH) activity (O'Sullivan et al., 2009). BSH split the peptide linkage of bile acids, which results in removal of the amino acid group from the steroid core. The resulting unconjugated 


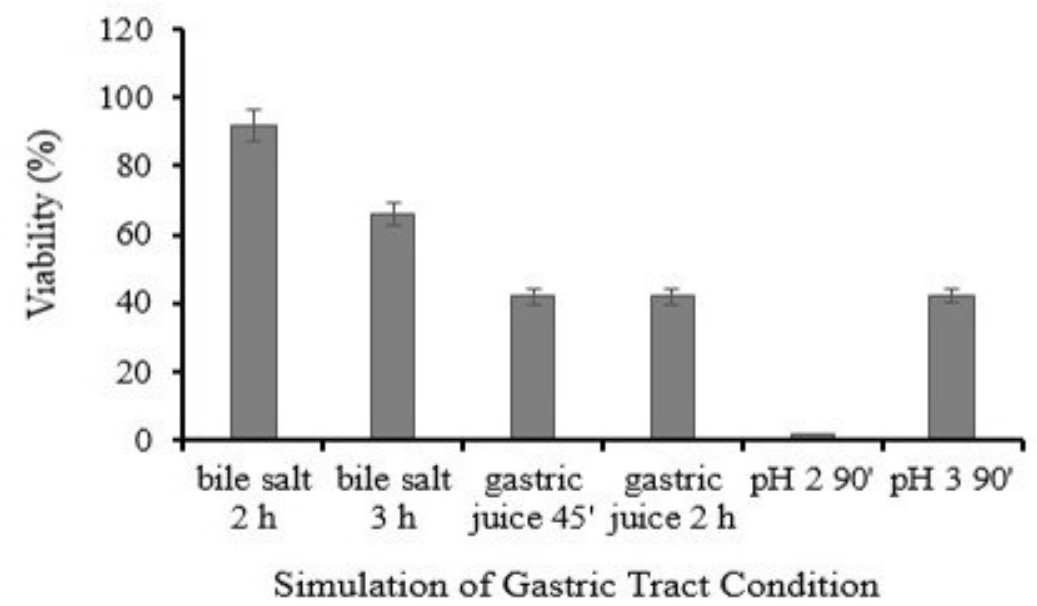

Figure 4. Viability Percentage of Saccharomyces cerevisiae M41 Isolated from Muscovy duck (Anas moschata) cecum

bile acids precipitate at low $\mathrm{pH}$ (Begley et al., 2006). Based on the ability to resist on bile salt, gastric juice and low $\mathrm{pH}, \mathrm{M} 41$ isolates had the same adaptation mechanism toward gastrointestinal stress condition.

\section{CONCLUSION}

Saccharomyces cerevisiae M41 isolated from Muscovy duck (Anas moschata) cecum have the cellulolytic activity with highest clear zone diameter $(0.64 \mathrm{~cm})$ between other yeast isolates from gastrointestinal tract of Javanese duck (Anas javanicus) and native chicken (Gallus javanicus). $S$. cerevisiae M41 have optimum growth cell condition the highest CMCase $(42.98 \mathrm{U} / \mathrm{mL})$ on $1 \% \mathrm{CMC}+0.1 \%$ glucose medium. In probiotic assay, S. cerevisiae M41 have highest viabilities $(91.91 ; 42.00 ; 42.13 \%)$ on bile salt, gastric juice and acid condition, respectively. It was concluded that $S$. cerevisiae M41 was potential yeast isolate as probiotic candidate for poultry with carboxymethyl cellulose (CMC) activity. Further research needs to be done in vivo on poultry animal to prove its ability as probiotic to improve digestibility and livestock performance.

\section{ACKNOWLEDGEMENT}

The research was funding under Entries List Project/DIPA 2016 of BPTBA LIPI, we would like to thank for the support, and thanks to Madina Nurohmah for supporting this research.

\section{REFERENCE}

Albersheim, P., A.G. Darvill, K.R. Davis, J.M. Lau, M. McNeil, J.K. Sharp, and W.S.York. 1984. Why study the structure of biological molecules? In: W.M. Dugger and S.Bartnicki-Garcia (Editors), Structure, Function and Biosynthesis of Plant Cell Walls. American Society of Plant Physiologists, Rockville, MD. 19-51.

Al-Shimmery, F.A. 2011. Investigation on the occurrence of yeast species in the digestive tracts of broiler. Proceedings, The $1^{\text {st }}$ International Conferences, Collage of Agricultural, University of Babylon, Iraq. P. 37-42.

Altschul, S.F., W. Gish, W. Miller, E.W. Myers and DJ. Lipman. 1990. Basic local alignment search tool. J Mol Biol. 215: 403-410.

Aprilyanto, V dan Sembiring, L. 2016. Filogenetik Molekuler: Teori dan Aplikasi. Cetakan Pertama. Innosain. Yogyakarta.

Arbeli, Z. and C.L. Fuentes. 2007. Improved purification and PCR amplification of DNA from environmental samples. FEMS Microbiol. Lett. 272(2): 269-275

Asmare, B. 2014. Effect of common feed enzymes on nutrient utilization of monogastric animals. Int. J. Biotechnol. Mol. Biol. Res. 5(4): 27-34.

Begley, M., C. Hill and C. G. M. Gahan. 2006. Bile salt hydrolase activity in probiotics. 
Appl. Environ. Microbiol. 72:1792-1738.

Belitz, H.D.,W. Grosch and P. Schieberle. 2008. Food Chemistry, $4^{\text {th }}$ ed. Berlin: SpringerVerlag. P.327-337.

Bhat, M.K. 2000. Cellulases and related enzymes in biotechnology. Biotechnol. Adv. 18(5): 355-383.

Brilhante, R. S. N., D. S. C. M. Castelo-Branco, G. D. P. Soares, D. J. Astete-Medrano, A. J. Monteiro, R. A. Cordeiro, J. J. C. Sidrim and M. F. G. Rocha. 2010. Characterization of the gastrointestinal yeast microbiota of cockatiels (Nymphicus hollandicus): a potential hazard to human health. J. Med. Microbiol. 59:718-723.

Chaucheyras, F., G. Fonty, P. Gouet, G. Bertin, and J.M. Salmon. 1996. Effects of a strain of Saccharomyces cerevisiae (Levucell ${ }^{\circledR}$ $\mathrm{SC}$ ), a microbial additive for ruminants, on lactate metabolism in vitro. Can. J. Microbiol. 42(9): 927-933.

Chorianopoulos, N.G., R.J.W. Lambert, P.N. Skandamis, E.T. Evergetis, S.A. Haroutounian and G.J.E. Nychas. 2006. A newly developed assay to study the minimum inhibitory concentration of Satureja spinosa essential oil. J. Appl. Microbiol. 100(4):778-786.

Cohort. 2008. CoSTAT Version 6.400. Cohort Software 798. Lighthouse Ave, Monterey, USA.

Czerucka D, Piche T, Rampal P. 2007. Review article: yeast as probiotics - Saccharomyces boulardii. Aliment Pharmacol. Ther. 26(6): 767-778.

Damayanti, E., H. Herdian, M. Angwar, A. Febrisiantosa, \& L. Istiqomah. 2012. Lactic acid bacterial screening from gastrointestinal digestive tract of native and broiler chicken for probiotic candidate purposes. J. Indonesian Trop. Anim. Agric. 37(3):168-175.

Damayanti., E, H. Julendra, A. Sofyan, and S. N. Hayati. 2014. Bile salt and acid tolerant of lactic acid bacteria isolated from proventriculus of broiler chicken. Med. Pet. 37(2): 80-86.

Felsenstein J. 1985. Confidence limits on phylogenies: An approach using the bootstrap. Evolution. 39(4):783-791.

Ferbiyanto, A., I. Rusmana, \& R. Raffiudin, 2015. Characterization and Identification of Cellulolytic Bacteria from gut of Worker Macrotermes gilvus. HAYATI. 22(4):197-
200.

Fikrinda, I. Anas, T. Purwadaria, D.A. Santosa. 2000. Isolasi dan seleksi bakteri penghasil selulase ekstremofil dari ekosistem air hitam. J. Mikrobiol. Indonesia. 5(2): 48-53.

Gao, J., H. Weng, D. Zhu, M. Yuan, F. Guan, and Y. Xi. 2008. Production and characterization of cellulolytic enzymes from the thermoacidophilic fungal Aspergillus terreus M11 under solid-state cultivation of corn stover. Bioresour. Technol. 99(16): 7623-7629.

Ghose, T.K. 1987. Measurement of cellulase activities. Pure App. Chem. 59(2): 257-268.

Gohel, H.R., C.N. Contractor, S.K. Ghosh, and V.J. Braganza. 2014. A comparative study of various staining techniques for determination of extra cellular cellulase activity on carboxy methyl cellulose (CMC) agar plates. Int. J. Curr. Microbiol. App. Sci. 3(5):261-266.

Goldbeck, R., C.C.P. Andrade, G.A.G. Pereira, and F.M. Filho. 2012. Screening and identification of cellulase producing yeastlike microorganisms from Brazilian biomes. Afr. J. Biotechnol. 11(53):11595-11603.

Gomez, K.A. and A.A. Gomez. 2007. Statistical Procedures for Agricultural Research $2^{\text {nd }}$ Ed. UI Press, Jakarta.

Hong, J., H. Yang, K. Zhang, C. Liu, S. Zou, M. Zhang. 2014. Development of a cellulolytic Saccharomyces cerevisiae strain with enhanced cellobiohydrolase activity. World J. Microbiol. Biotechnol. 30(11):29852993.

Ikram-ul-haq, M.M. Javed, T.S. Khan, and Z. Siddiq, 2005. Cotton Saccharifying Activity of Celulaces Produced by Co-culture of Aspergillus niger and Trichoderma viride. Res. J. Agric. Biol. Sci. 1(3): 241-245.

Imran, M., Z. Anwar, M. Irshad, M.J. Asad, and H. Ashfaq. 2016. Cellulase production from species of fungi and bacteria from agricultural wastes and its utilization in industry: A Review. Advances in Enzyme Res. 4(2):44-55.

Kanti, A., and I. M. Sudiana. 2002. Cellulolytic yeast isolated from Soil Gunung Halimun National Park. Berita Biologi. 6(1):85-90.

Kanti, A., I.M. Sudiana dan H.J.D. Latupapua. 2003. Aktivitas CMC-ase khamir Candida sp. yang diisolasi dari tanah Kebun Biologi Wamena, Papua. Berita Biologi 6(5):655660. 
Kanti, A., N. Sukarno, E. Sukara and L. K. Darusman. 2012. Cellulolytic yeast isolated from Raja Ampat Indonesia. Ann. Bogor. 16(1):16:1-8.

Kasana, R.C., R. Salwan, H. Dhar, S. Dutt, and A. Gulati. 2008. A Rapid and easy method for the detection of microbial cellulases on agar plates using gram's iodine. Curr. Microbiol. 57(5): 503-507.

Krieg, N.R., J.T. Staley, D.R. Brown, B.P. Hedlund, B.J. Paster, N.L. Ward, W. Ludwig, and W.B. Whitman. 2010. In Bergey's Manual of Systematic Bacteriology. (N. R. Krieg, J. T. Staley, D. R. Brown, B. P. Hedlund, B. J. Paster, N. L. Ward, W. Ludwig \& W. B. Whitman, eds). New York: Springer.P. 54-358

Kumar S., Stecher G., and Tamura K. (2016). MEGA7: Molecular Evolutionary Genetics Analysis version 7.0 for bigger datasets. Molecular Biology and Evolution 33(7):1870-1874.

Kurtzman, C.P. and C.J. Robnett. 1998. Identification and phylogeny of ascomycetous yeasts from analysis of nuclear large subunit (26s) ribosomal DNA partial sequences. Antonie van Leeuwenhoek. 73(4): 331-371.

Laubscher, W.D.F., B.C. Viljoen, and J. Albertyn. 2000. The yeast flora occuring in the trachea of broiler chicken. Food Technology and Biotechnology. 38(1):7788.

Liang, Y. L., Z. Zhang, M. Wu, Y. Wu, and J. X. Feng. 2014. Isolation, screening, and identification of cellulolytic bacteria from natural reserves in the subtropical region of China and optimization of cellulase production by Paenibacillus terrae ME271. BioMed Res. Inter. ID 512497.

Maki M., K.T. Leung, and W. Qin. 2009. The prospects of cellulase-producing bacteria for the bioconversion of lignocellulosic biomass. Int. J. Biol. Sci. 5(5):500-16.

Markowiak, P. and K. Śliżewska. 2018. The role of probiotics, prebiotics and synbiotics in animal nutrition Gut Pathog 10(21):1-20

Meryandini, A., V. Melani, and T.C. Sunarti. 2011. Addition of cellulolytic bacteria to improved the quality of fermented cassava flour. Afr. J. Food Sci. Technol. 2(2):30-35.

Morana, A. M. 2011. Cellulase from fungi and bacteria and their biotechnological applications, in Cellulase: types and action, mechanism, and uses (A. E. Golan, ed). Nova Science Publishers, Inc, New York.

Musikasang, H., A. Tani, A. H-kittikun, and S. Maneerat. 2009. Probiotic potential of lactic acid bacteria isolated from chicken gastrointestinal digestive tract. World J. Microbiol. Biotechnol. 25(8):1337-1345.

Muthuvelayudham, R. and T. Viruthagiri. 2006. Fermentative production and kinetics of cellulase protein on Trichoderma reesei using sugarcane bagasse and rice straw. Afr. J. Biotechnol. 5(20):1873-1881.

O'Sullivan, O., J. O'Callaghan, A. SangradorVegas, O. McAuliffe, L. Slattery, P. Kaleta, M. Callanan, G. F. Fitzgerald, R. P. Ross and $\mathrm{T}$. Beresford. Comparative genomics of lactic acid bacteria reveals a niche-specific gene set. 2009. BMC Microbiol. 9(50):1-9.

Palmer, T. and P. L. Bonner. 2011. Biotechnological Applications of Enzymes, in Enzymes second edition. Biochemistry, Biotechnology, Clinical Chemistry. Woodhead Publishing. Cambridge.

Pavlostathis, S.G., T.L. Miller and M.L. Wolin. 1998. Fermentation of insoluble cellulose by continuous culture of Ruminococcus albus. Appl. Environ. Microbiol. 54(11):2655-2659

Rajkowska, K. and A. Kunicka-Styczyñska. 2010. Probiotic properties of yeasts isolated from chicken feces and kefirs. Pol. J. Microbiol. 59(4):257-263

Roto, S.M., P.M. Rubinelli and S.C. Ricke. 2015. An introduction to the avian gut microbiota and the effects of yeast based prebiotic-type compounds as potential feed additives. Front. Vet. Sci. 2(28):1-19.

Sazci, A., A. Radford and K. Erenle. 1986. Detection of cellulolytic fungi by using Congo red as an indicator : a comparative study with the dinitrosalicyclic acid reagent method. J. Appl. Bacteriol. 61:559-562.

Shurson, G. C. 2018. Yeast and yeast derivatives in feed additives and ingredients: sources, characteristics, animal responses, and quantification methods. Anim. Feed Sci. Technol. 235:60-76.

Sofyan, A., A.N Aswari, T. Purwoko and E. Damayanti. 2013. Screening of lactic acid bacteria from rumen liquor and king grass silage as well as their antibacterial activities. Med.Pet. 36(3):216-223.

Sourabh, A., S. S. Kanwar and O. P. Sharma. 2012. In vitro characterization of 
Saccharomyces cerevisiae HM535662 obtained from an indigenous fermented food "Bhaturu" of Western Himalayas. Afr. J. Biotechnol. 11(52):11447-11454.

Sutton, S. 2011. Measurement of microbial cells by optical density. J. Val. Technol. (Winter, 2011) 46-49.

Syal, P. and A. Vohra. 2013. Probiotic potential of yeasts isolated from traditional Indian fermented foods. Int. J. Microb. Res. 5(2): 390-398.

Szermer-Olearnik, B., M. Sochocka, K. Zwolińska, J. Ciekot, A. Czarny3, J. Szydzik, K. Kowalski and J. Boratyński. 2014. Comparison of microbiological and physicochemical methods for enumeration of microorganisms. Postepy Hig Med Dosw. 68:1392-1396.

Tamura K. and M. Nei. 1993. Estimation of the number of nucleotide substitutions in the control region of mitochondrial DNA in humans and chimpanzees. Mol. Biol. Evol. 10(3):512-526.

Teather R.M. and Wood P.J. 1982. Use of Congo red-polysaccharide interactions in enumeration and characterization of cellulolytic bacteria from the bovine rumen. Appl Environ Microbiol. 43(4):777-780.

Thongekkaew, J. and J. Kongsanthia. 2016. Screening and identification of cellulase producing yeast from Rongkho Forest, Ubon Ratchathani University. Bioeng.
Biosci. 4(3):29-33

Torshizi, M.K., S. Rahimi, N. Mojgani, S. Esmaeilkhanian and J.L. Grimes. 2008. Screening of indigenous strains of lactic acid bacteria for development of a probiotic for poultry. Asian-Aust. J. Anim. Sci. 21(10): 1495-1500.

Valjamae, P. 2002. The kinetics of cellulose enzymatic hydrolysis. Implications of the synergism between enzymes. PhD Thesis. Uppsala University. Uppsala.

Van Uden, N. and O. Castelo-Branrco. 1963. Distribution and population densities of yeast species in Pacific water, air, animals, and kelp off Southern California. Limnol.Oceanog. 8:323-329.

Walugembe., M. 2013. The effect of high and low dietary fiber diets on the performance of two lines of chickens with divergent growth rates. $\mathrm{PhD}$ Thesis. Iowa State University, Iowa

Yang, W. 2014. Isolation and identification of a cellulolytic bacterium from the Tibetan pig's intestine and investigation of its cellulase production. Electronic J. Biotechnol. 17(6):262-267.

Zhang, A.W., B.D. Lee, S.K. Lee, K.W. Lee, G.H. An, K.B. Song and C.H. Lee. 2005. Effects of yeast (Saccharomyces cerevisiae) cell components on growth performance, meat quality, and ileal mucosa development of broiler chicks. Poul. Sci. 84(7):1015-1021. 